Louisiana State University

LSU Digital Commons

Faculty Publications

Department of Geography \& Anthropology

2009

\title{
The role of black Barbudans in the establishment of open-range cattle herding in the colonial Caribbean and South Carolina
}

Andrew Sluyter

Louisiana State University, asluyter@lsu.edu

Follow this and additional works at: http://digitalcommons.lsu.edu/geoanth_pubs

\section{Recommended Citation}

Sluyter, Andrew, "The role of black Barbudans in the establishment of open-range cattle herding in the colonial Caribbean and South Carolina" (2009). Faculty Publications. 29.

http://digitalcommons.lsu.edu/geoanth_pubs/29 


\title{
The role of black Barbudans in the establishment of open-range cattle herding in the colonial Caribbean and South Carolina
}

\author{
Andrew Sluyter \\ Department of Geography and Anthropology, Louisiana State University, 227 Howe-Russell Geosciences Complex, \\ Baton Rouge, LA 70803-4105, United States
}

\begin{abstract}
Some significant problems remain in understanding the establishment of open-range cattle herding in the Caribbean and North America, especially regarding the role of blacks in that process. Research to date has identified the Greater Antilles, especially Spanish Cuba and British Jamaica, as the sole Caribbean sources of settlers who established the herding systems of, respectively, Mexico and South Carolina. Yet an open-range cattle herding system also occurred in the British Lesser Antilles, which provided many of the settlers for the South Carolina colony. Archival and field research in Antigua and Barbuda provide the basis for comprehensive reconstruction of that system's material culture and herding ecology, demonstration of the role of blacks in its operation, and comparison with other relevant systems to consider whether the British Lesser Antilles might also have been involved in the process through which open-range cattle herders established themselves in South Carolina during the late seventeenth century.
\end{abstract}

(C) 2008 Elsevier Ltd. All rights reserved.

E-mail address: asluyter@1su.edu

0305-7488/\$ - see front matter (C) 2008 Elsevier Ltd. All rights reserved. doi:10.1016/j.jhg.2008.08.003 
[C]onsider the proposition that slaves may have actively shaped landscapes of the Americas not solely by their brawn but also with their brains. ${ }^{1}$

\section{Black brawn, black brains}

The role of Africans in establishing open-range cattle herding in the Caribbean and North America remains unresolved. In general, the literature on creation of the colonial landscapes of the Americas has long emphasized the role played by the labor of enslaved blacks over their ideas and practices, both those that survived the Middle Passage and those created through innovation and hybridization with the ideas and practices of natives and Europeans. In part such an emphasis on 'black brawn' over 'black brains' derives from reliance on documentary archives created by racially biased whites. And in part not only the accumulation of those archives but their later use by historians has taken place within a Eurocentric colonizer's model of the world, in which all creativity and innovation diffused from Europe to its colonies. Only relatively recently has study of the interconnected Atlantic world using alternative sources such as slave diaries, oral histories, archaeological artifacts, and landscape vestiges begun to uncover major black contributions beyond labor to the creation of colonial American places. Regarding the South Carolina colony, established around Charleston in 1670, such revisionism has revealed the major role of black agricultural knowledge in creating the landscape of rice cultivation that came to dominate the coastal lowlands in the 1700s (Fig. 1). ${ }^{2}$

A focus on the processes that interconnected the colonial Atlantic combined with the use of a mix of sources has begun to uncover a similar role for blacks in the establishment of the open-range cattle herding that dominated lowland South Carolina before the rice boom. The relevant sources encompass not only archival documents but also oral histories, artifacts, and landscape vestiges. And the focus on the

\footnotetext{
${ }^{1}$ J. Carney, Landscape legacies of the African diaspora in Brazil, Progress in Human Geography 27 (2003) 139-152; quote from p. 145.

2 J.M. Blaut, The Colonizer's Model of the World: Geographical Diffusionism and Eurocentric History, New York, 1993; A. Sluyter, The making of the myth in postcolonial development: material-conceptual landscape transformation in sixteenth-century Veracruz, Annals of the Association of American Geographers 89 (1999) 377-401; A. Sluyter, Colonialism and landscape in the Americas: material/conceptual transformations and continuing consequences, Annals of the Association of American Geographers 91 (2001) 410-428; A. Sluyter, Blaut's early natural/social theorization, cultural ecology, and political ecology, Antipode 37 (2005) 963-980; A. Sluyter and K. Mathewson, Intellectual relations between historical geography and Latin Americanist geography, Journal of Latin American Geography 6 (2007) 25-41; J. Thornton, Africa and Africans in the Making of the Atlantic World, 1400-1800, Cambridge, 1998; J.D. Edwards, Open issues in the study of the historic influences of Caribbean architecture on that of North America, Material Culture 37 (2005) 44-84; A. Ogundiran and T. Falola (Eds), Archaeology of Atlantic Africa and the African Diaspora, Bloomington, Indiana, 2007; J. Carney, Black Rice: the African Origins of Rice Cultivation in the Americas, Cambridge, Massachusetts, 2001; J. Carney, Agroenvironments and slave strategies in the diffusion of rice cultivation to the Americas, in: K.S. Zimmerer and T.J. Bassett (Eds), Political Ecology: an Integrative Approach to Geography and Environment-Development Studies, New York, 2003, 256-273.
} 


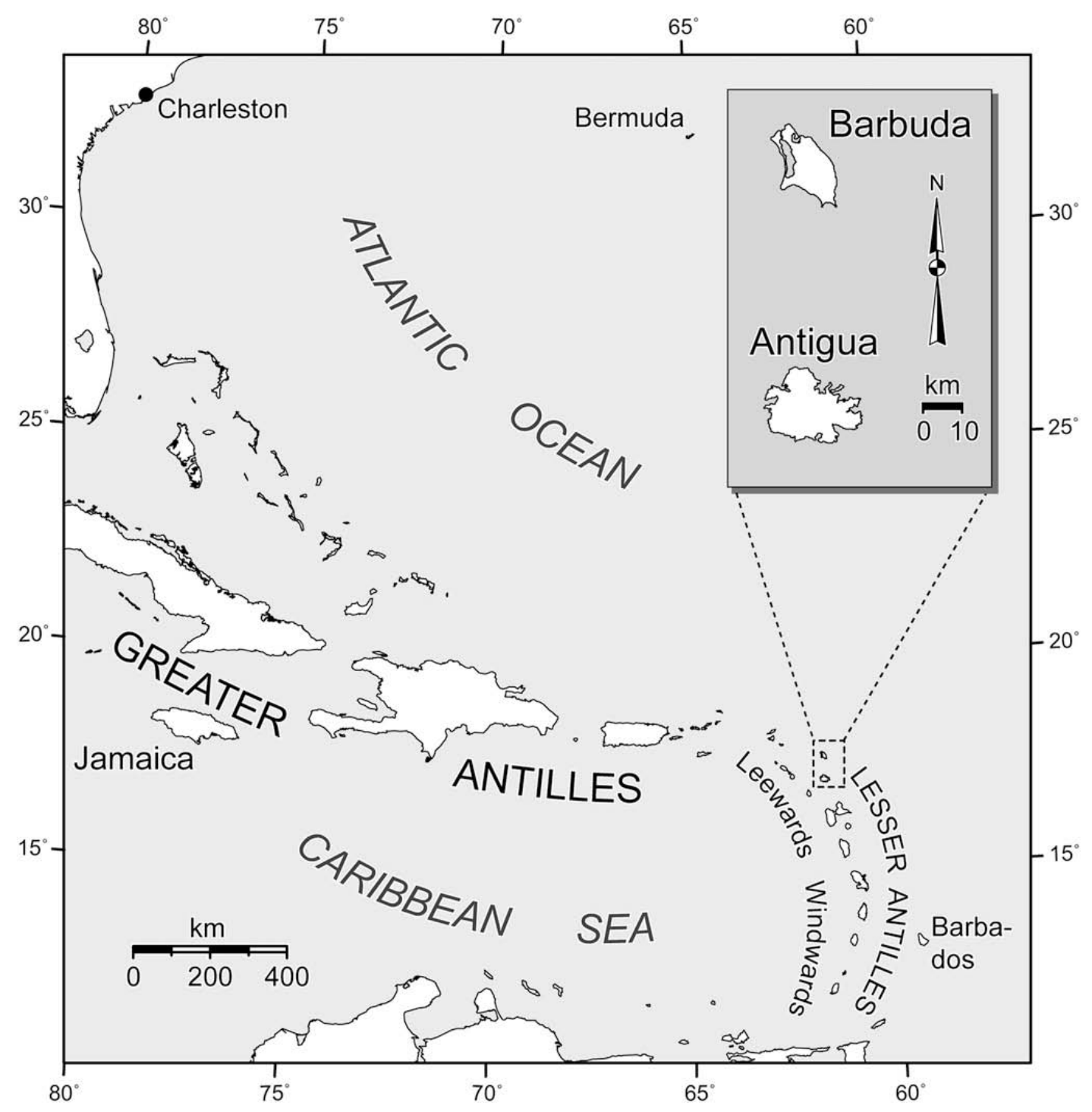

Fig. 1. Location of Barbuda and other places relevant to text.

network of processes that connected South Carolina and Africa shifts much of the research emphasis to the Caribbean borderlands, scene of so much of the hybridization among African, European, and native knowledge systems and practices that subsequently affected other places in the Americas.

\section{Establishment of open-range cattle herding}

The general process through which open-range cattle herding became established in the Caribbean and North America seems clear enough. People familiar with the sixteenth-century herding systems of the highlands of the British Isles, the marshes of Andalusian Spain, and 
the sub-Saharan steppes of West Africa modified and hybridized them in the Caribbean after 1492 to produce distinct Antillean systems. That process continued when colonizers from the Antilles established open-range herding in Mexico in the early sixteenth century and in South Carolina in the late seventeenth century, with further modification of those Antillean systems on the mainland. Herders then pushed their respective ranching frontiers north from Mexico and west from South Carolina until intersection in the Texas-Louisiana borderlands during the eighteenth century. The distinctive open-range herding system that emerged there came to dominate much of the Great Plains during a brief florescence in the late nineteenth century before barbed wire closed the range. ${ }^{3}$

One respect in which that general understanding lacks precision involves the processes relating the Caribbean to South Carolina, including such issues as where in the British West Indies the initial South Carolinian cattle herders came from and whether blacks played a role beyond labor in the system they established. Research to date has identified Jamaica as the sole Caribbean source of the herders who settled in South Carolina after 1670 and who, together with others from Britain and perhaps Africa, established an open-range system. The Jamaica system itself incorporated a mix of Spanish and British herding practices, with the issue of an African contribution other than labor remaining, to quote Terry Jordan, 'problematical.' Yet Jamaica seems an unlikely source because most of the South Carolinian settlers came from the Lesser Antilles, especially Barbados. Nonetheless, an assumption that only the Greater Antilles had open-range cattle herding, with the Lesser Antilles dedicated entirely to sugar plantations, has supported the conclusion that British-held Jamaica must have been the sole Caribbean source of the settlers who established the South Carolinian herding system. ${ }^{4}$

The results of field and archival research during summer 2007 challenge that assumption by documenting that at least one of the British Lesser Antilles, namely the island of Barbuda, had an open-range cattle herding system operated by blacks throughout colonial times (Fig. 2). Other researchers have described Barbudan cattle herding mainly in passing, while focused on other research problems such as vegetation history, coastal geomorphology, social and economic history, and archaeology. Only the anthropologist Riva Berleant-Schiller has systematically documented

\footnotetext{
${ }^{3}$ T.G. Jordan, North American Cattle-Ranching Frontiers: Origins, Diffusion, and Differentiation, Albuquerque, 1993 remains the authoritative text on the topic; more recent elaborations include A. Sluyter, The ecological origins and consequences of cattle ranching in sixteenth-century New Spain, The Geographical Review 86 (1996) 161-177; N. Sayre, The cattle boom in southern Arizona: towards a critical political ecology, Journal of the Southwest 4 (1999) 239-271; A. Sluyter, Colonialism and Landscape: Postcolonial Theory and Applications, New York, 2002; and B. Jones, Louisiana Cowboys, Gretna, Louisiana, 2007.

${ }^{4}$ Jordan, North American Cattle-Ranching Frontiers (note 3), 78-84, 109-120, 311-312, with the quote from p. 82; P.H. Wood, 'It was a negro taught them': a new look at African labor in early South Carolina, Journal of Asian and African Studies 9 (1974), 160-179; P.H. Wood, Black Majority: Negroes in Colonial South Carolina from 1670 through the Stono Rebellion, New York, 1974, 28-34; J.S. Otto and N.E. Anderson, Cattle ranching in the Venezuelan Llanos and the Florida Flatwoods, Comparative Studies in Society and History 28 (1986), 672-683; J.S. Otto and N.E. Anderson, The origins of southern cattle-grazing: a problem in West Indian history, The Journal of West Caribbean History 21 (1988), 138-153; the standard text on the historical geography of the Caribbean, D. Watts, The West Indies: Patterns of Development, Culture and Environmental Change since 1492, Cambridge, 1987, associates open-range cattle herding exclusively with the Greater Antilles.
} 


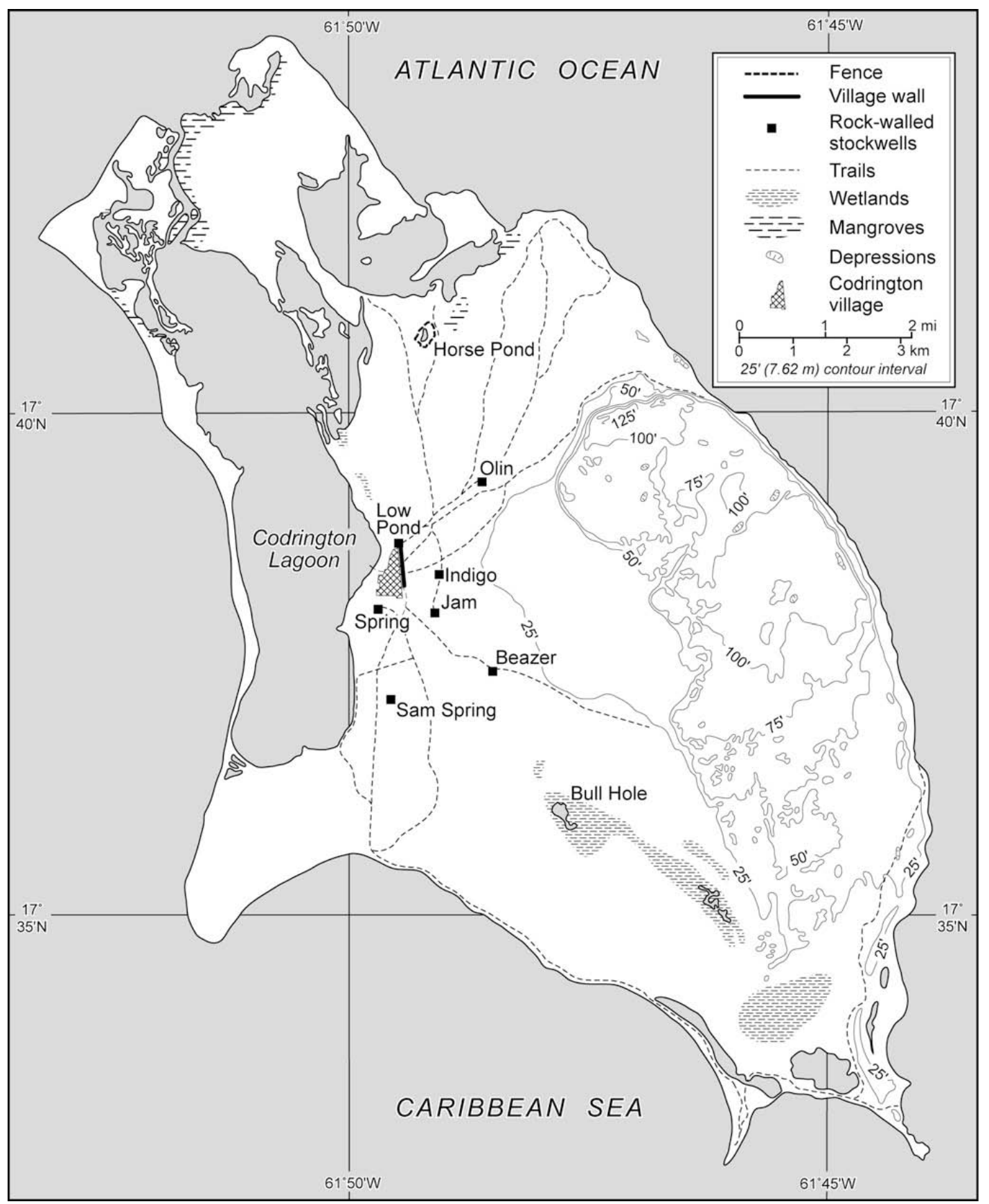

Fig. 2. Map of Barbuda showing rock-walled stockwells, village wall, and other relevant landscape elements circa 1968. 
some aspects of its material culture and herding ecology, mainly those related to Barbudan society and economy in the 1970s. ${ }^{5}$

In contrast, field observation of vestigial landscape elements on Barbuda, archival research on Antigua, and oral histories derived from interviews with the few remaining 'cattle runners' provide a first comprehensive description of the herding system's colonial material culture and ecology. That reconstruction allows comparison of the Barbudan system to those of Jamaica and South Carolina, consideration of whether people from the Leeward Lesser Antilles might have influenced the establishment of the South Carolinian system, and evaluation of whether blacks played a creative role in that process.

\section{The Barbudan open range}

Precisely when cattle and other livestock first arrived on Barbuda remains unclear. The Spaniards made abortive colonization attempts in the Leewards during the 1520s, possibly on Barbuda and certainly on neighboring Antigua. Before the native Caribs expelled the Spaniards, they might have followed their usual practice of introducing livestock. A series of occupations of Barbuda by the British beginning in the late 1620s, intermittent at first but becoming effectively continuous in 1666, must certainly have introduced large livestock because by 1676 the island had a reputation for its herds of cattle and horses. ${ }^{6}$

Barbuda's status as an open-range continued throughout colonial times. Between 1668 and 1898, the Crown leased out the use of the entire island, with the Codrington family holding it from 1685 through 1870. Repeated attempts to establish plantations for cotton and other crops failed due to shallow soils, average annual rainfall of only $900 \mathrm{~mm}$, long winter dry season, frequent droughts, and paucity of surface water. Instead, sales of cattle for beef to the Royal Navy and draught oxen to sugar plantations on neighboring islands yielded most of the income from Barbuda, with the remainder from salvage of ships wrecked on the island's many reefs and sales of mules, horses, sheep, goats, leather, wood, charcoal, fish, manure, turtles, salt, and other provisions. In contrast to

\footnotetext{
${ }^{5}$ D.R. Harris, Plants, Animals, and Man in the Outer Leeward Islands, West Indies: an Ecological Study of Antigua, Barbuda, and Anguilla, Berkeley, 1965; R.J. Russell and W.G. McIntire, Barbuda Reconnaissance, Baton Rouge, 1966; D. Lowenthal and C. Clarke, Slave-breeding in Barbuda: the past of a Negro myth, Annals of the New York Academy of Sciences 292 (1977) 510-535; D. Lowenthal and C. Clarke, Triumph of the commons: Barbuda belongs to all Barbudans together, in: J. Besson and J. Momsen (Eds), Caribbean Land and Development Revisited, New York, 2007, 147-158; R. Berleant-Schiller, Subsistence and social organization in Barbuda, West Indies, doctoral dissertation, Anthropology, State University of New York at Stony Brook, 1974; R. Berleant-Schiller, Production and division of labor in a West Indian peasant community, American Ethnologist 4 (1977) 253-272; R. BerleantSchiller, The social and economic role of cattle in Barbuda, The Geographical Review 67 (1977) 299-309; R. Berleant-Schiller, Grazing and gardens in Barbuda, in: R. Berleant-Schiller and E. Shanklin (Eds) The Keeping of Animals: Adaptation and Social Relations in Livestock Producing Communities, Totowa, New Jersey, 1982, 73-91; R. Berleant-Schiller, Hidden places and creole forms: naming the Barbudan landscape, The Professional Geographer 43 (1991) 92-101; D.R. Watters, Observations on the historic sites and archaeology of Barbuda, Journal of Archaeology and Anthropology 3 (1980) 125-154; M.T. Tweedy, A History of Barbuda Under the Codringtons, 1738-1833, M.Litt. thesis, Department of History, University of Birmingham, 1981.

${ }^{6}$ C.O. Sauer, The Early Spanish Main: the Land, Nature, and People Columbus Encountered in the Americas, Berkeley, 1966, 192-94; A.W. Crosby, The Colombian Exchange: Biological and Cultural Consequences of 1492, Westport, Connecticut, 1972, 78; Harris, Plants, Animals, and Man (note 5), 79-85, 91; Watts, The West Indies (note 4), 115-117, 169.
} 
neighboring Antigua, St. Kitts, and Nevis, so thoroughly dominated by sugar plantations during the 1700s and 1800s, Barbuda's lack of private property and land enclosure, other than to exclude stock from the lone village of Codrington and a few perennially faltering agricultural fields, helped to ensure that open range persisted through emancipation in 1834, termination of the last lease in 1898 , and subsequent direct management by the Colonial Office. ${ }^{7}$

Beginning with associated statehood in 1969 and escalating with independence as the country of Antigua and Barbuda in 1981, Barbudans have argued that the island became their communal property rather than public domain. Land has thus remained un-alienated and mostly unfenced. Some 2000 feral cattle as well as additional horses, sheep, goats, donkeys, wild pigs, and deer continue to range throughout the $160 \mathrm{~km}^{2}$ island. Yet open-range cattle herding has become largely moribund since independence, with only a single crew of cattle runners currently hunting the feral cattle. ${ }^{8}$

\section{Recent cattle herding}

The three young men who now hunt cattle do so as a diversion from their jobs and to earn extra cash. They periodically ride out on horses with a pack of pit bulls to hunt down the small, shorthorned, feral cattle. The cattle hunts typically begin Friday at midnight in order to sell the meat Saturday morning to locals for family barbeques or, given a large enough animal, on the hoof to a butcher on Antigua. The crew chases the cattle on horseback until a large cow or bull tires enough that the pit bulls can corner it and latch their teeth in its face and neck to bring it to its knees. The cattle runners then rush in on foot to tie a rope around the animal's horns to lead it back to Codrington for slaughter. Another technique, for bringing down smaller animals, requires a flying leap from horseback to wrestle the animal to the ground, similar to the bulldogging event of North American rodeos. The cattle runners also use a tail twisting technique, similar to the coleadero event in the charreadas of Mexico and parts of the US Southwest and the coleo of Venezuela and Colombia. That technique involves riding or running up behind a bull and twisting its tail to make it lose balance and stumble. Since the feral cattle occur in such abundance relative to demand, with estimates ranging from 1500 to 2500 head of cattle compared to the human population of 1325 , they effectively comprise unbranded, communal property that the cattle runners sporadically hunt down. Commercial beef production has instead come to focus on small herds of recently introduced zebu crossestethered while grazing, paddocked at night, and tame in contrast to the feral stock. ${ }^{9}$

\footnotetext{
${ }^{7}$ D.V. Nicholson, Antigua, Barbuda, and Redonda: an Historical Sketch, St. John's, Antigua, 1991; D. Hall, Five of the Leewards 1834-1870: the Major Problems of the Post-emancipation Period in Antigua, Barbuda, Montserrat, Nevis and St. Kitts, Aylesbury, Bucks, 1971, 59-95; Harris, Plants, Animals, and Man (note 5), 9-10, 19-23, 35-39; Tweedy, A History of Barbuda (note 5), 78, 161-63.

${ }^{8}$ R. Coram, Caribbean Time Bomb: the United States' Complicity in the Corruption of Antigua, New York, 1993, 96112; Lowenthal and Clarke, Triumph of the commons; June 2007 Field Book, interviews; on the reasons for the postindependence decline in cattle herding, see A. Sluyter and A.E. Potter, Recent change in Barbudan open-range cattle herding and communal land tenure, Manuscript submitted to Journal of Cultural Geography on 15 July 2008.

9 June 2007 Field Book, interviews (note 8); 2001 Census of Population and Housing, Summary Report, Vol. 1, St. John's, Antigua, 2004; for a particularly gripping account of the coleo, see pp. 183-184 in R. Paez, Wild Scenes in South America: or, Life in the Llanos of Venezuela, New York, 1862.
} 


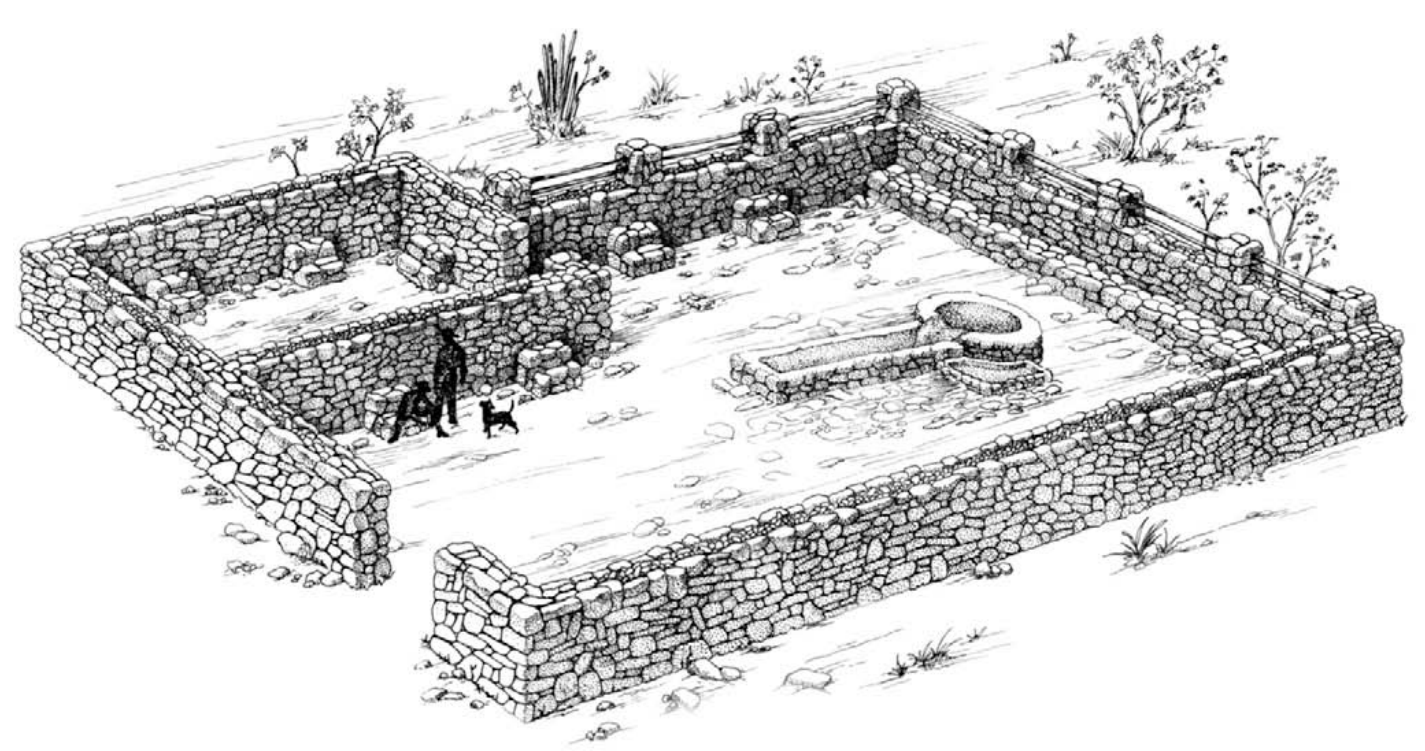

Fig. 3. Sketch encompassing architectural elements of all known rock-walled stockwells on Barbuda.

That the colonial herding system consisted of more than such cattle hunting becomes evident from the many relict rock-walled stockwells that persist around Codrington (Fig. 3). Those stockwells, like the island in general, remain common property. Four of them have largely intact walls: Indigo, Jam, Beazer, and Olin Wells. Two more, Spring and Sam Spring Wells, retain but the barest remnants of such walls. A rock wall also surrounds Low Pond, a natural water hole. Some of the wells have alternate names: John instead of Jam Well; Beazels instead of Beazer Well; and All In or Only instead of Olin Well. Poor repair characterizes all the stockwells, with several having broken drinking troughs and all but Olin Well lacking buckets to draw water. The Barbuda Council has designated five of the stockwells as historic sites and efforts to repair, if not quite restore, them remain underway. In the meantime, goats and donkeys drink at any of the wells with intact troughs whenever rainwater accumulates or someone draws water with a portable pump. They also drink at Low Pond despite the overgrowth of shrubs. Surveys of groundwater resources dating to the late colonial period record a dozen other wells dotting the lowlands, none of them enclosed by rock walls but a few of them such as Bumpy and Highland Wells with drinking troughs and enclosures of wire fencing. ${ }^{10}$

Generally the design of the rock-walled wells suggests use by large stock even though interviews and the lack of cow flops testify that cattle no longer drink there. The wells themselves consist of a coaming some $4 \mathrm{~m}$ in diameter and $0.75 \mathrm{~m}$ high built of mortared limestone

\footnotetext{
${ }^{10}$ Barbuda Topographic Map, 1:25,000, 2 sheets, Surbiton, Surrey, 1970; Barbuda Topographic Map, 1:10,000, 9 sheets, Surbiton, Surrey, 1970; June 2007 Field Book, maps and sketches; P.H.A. Martin-Kaye, The Water Resources of Antigua and Barbuda, St. John's, Antigua, 1956; J.D. Mather, A Survey of the Ground Water Resources of Barbuda, London, 1971.
} 
blocks, with the water table $2-3 \mathrm{~m}$ below ground level. Of identical construction as the coamings and built into their sides, the drinking troughs measure about $9 \mathrm{~m}$ long, $1.5 \mathrm{~m}$ wide, and $0.7 \mathrm{~m}$ high. At some wells, shallower pans ranging from 1 to $3 \mathrm{~m}$ on a side and $0.3-0.4 \mathrm{~m}$ high serve small stock. The troughs and pans rest directly on the coral limestone bedrock that, except for occasional patches of soil, floors the enclosures. Based on Olin Well, people raised water to the surface with a bucket attached by a rope to a windlass, dumping the water onto a short flume built into the end of the trough nearest the coaming. The walls that enclose the wells have a width of $0.75-1 \mathrm{~m}$ and a height of 2-2.5 m. Most of the enclosures consist of dry-laid inner and outer walls filled with rubble except near entrances and corners, where solid, mortared walls provide greater strength. Rather than continuous upper courses, the highest walls consist of double wooden rails. A continuous ledge about $0.5 \mathrm{~m}$ high or, in some cases, a series of discontinuous steps runs around the bases of many of the walls. An opening of some $3 \mathrm{~m}$ width gives entry to each enclosure, with a narrower opening leading into a smaller enclosure built into a corner of the main enclosure. Iron hinge pins mortared into the sides of those openings indicate that gates once controlled access to the main and smaller enclosures. Only Indigo Well, however, retains the type of double gate of wooden pickets that probably used to be common to all, while the remains of wire mesh gates lay beside both entrances at Olin Well. ${ }^{11}$

The oral history of retired cattle herders combined with descriptions from Berleant-Schiller's dissertation and field notes explains how those rock-walled stockwells functioned during the 1900s. Crews of cattle runners typically numbered four to six men who employed two ways of catching cattle: hunting them on the open range at any time of year and trapping them at the walled wells during the winter dry season. In the bush, the crews used similar techniques as at present, chasing a herd on horseback until a cow or bull tired enough to be cut out and brought down with dogs, a cattle runner on foot with a lasso, bulldogging, or a tail twist. At the walled wells, the crews watched at night during the dry season. When cattle entered the main enclosure to drink, the cattle runners would shut the gate and chase the animals into the smaller enclosure, known as the 'kitchen pen,' derived from catching pen. Once all the stock had entered the catching pen, the crew shut its gate and reopened the main one so more cattle could enter to drink. Fencing around Horse Pond, a perennial water hole near the north coast, denied cattle that water source and forced more to the walled wells. Inside the catching pen, cattle runners subdued the cattle with tail twisting, lassoing from atop the walls, or bulldogging. Anytime a bull would turn on a cattle runner, the built-in steps provided an escape route to the top of the wall. Once subdued, the cattle runners tied the cattle together in a line to lead them to Codrington, with half of the crew holding onto the rope ahead of the column and the other half behind. ${ }^{12}$

Barbudans of the 1900s considered cattle running a prestigious occupation, and the crews both owned cattle themselves and herded for other owners, most of whom had half a dozen head but

\footnotetext{
${ }^{11}$ June 2007 Field Book, maps, sketches, and interviews.

12 June 2007 Field Book, interviews (note 8); Berleant-Schiller, Subsistence and social organization in Barbuda (note 5); NAA (National Anthropological Archives), Smithsonian Institution, Washington, DC, R. Berleant-Schiller Papers, Acc. 2005-12.
} 


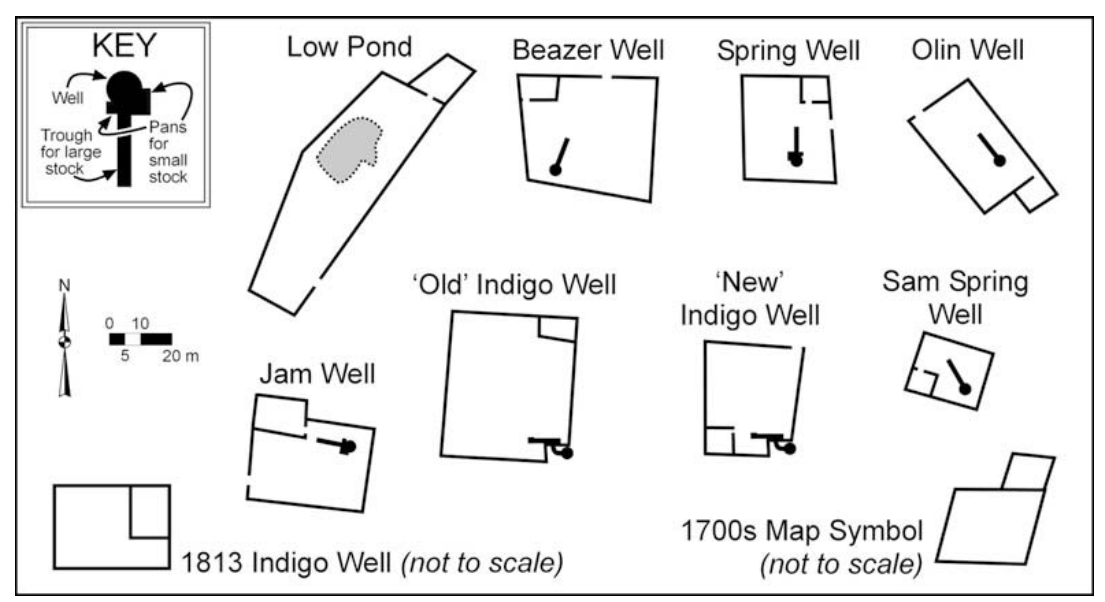

Fig. 4. Plans of the seven rock-walled stockwells extant on Barbuda circa 1968 and those on maps of 1813 and the 1700 s.

a few of whom had up to a hundred. Brands and ear marks established ownership, and the beef provided cash income though live exports to Antigua as well as feeding Barbudans. For example, a calf in the early 1970s had a value of $\$ 70$ Eastern Caribbean Dollars, a breeding cow $\$ 150$, and a bull from \$150-230 depending on size, which could range from a small $400 \mathrm{lbs}$ to an even smaller 250 lbs. The cattle runners were aged between 25 and 45, and they earned $\$ 30$ per crew for every animal caught on commission for another owner. ${ }^{13}$

Systematic analysis of the form of the well enclosures uses aerial and ground-level photographs that antedate the dismantling and crushing of some walls for airstrip and road construction during the 1970s, including the wall that used to exclude livestock from Codrington. Together with field mapping in June 2007, the archival photographs yield plans for each of the known walled wells (Fig. 4). The plans reveal a relatively consistent model for form but with some variation in size. Except for Low Pond and Indigo Well, all have the keyhole-plan well and trough as well as, in some cases, an additional watering pan or pans for smaller stock. Low Pond instead relies on a pool of brackish water and Indigo Well on a well located outside of the enclosure, with the top of the coaming level with the top of the wall, that delivers water to a trough and pan via a curved flume and hole through the wall. The name and atypical configuration suggest indigo processing might once have occurred at this well, but if so no evidence remains of the usual cascade of three vats. The aerial photographs also reveal that Indigo Well had a larger enclosure before reconstruction in the 1970s, and Berleant-Schiller's photograph collection confirms that the rebuilding retained the same well, flume, and trough configuration. The locations of the two entrances at 'Old' Indigo Well as well as of the entrance to the main enclosure at Sam Spring Well remain indeterminable due to the limitations of the aerial photographs and the informants' memories. In terms of size, the main enclosures range from $1991 \mathrm{~m}^{2}$ for Low Pond to $443 \mathrm{~m}^{2}$ for Sam Spring Well, while the catching pens range from $186 \mathrm{~m}^{2}$ for Jam Well to $57 \mathrm{~m}^{2}$ for Spring Well and, as a proportion of the main enclosure, from $20 \%$ for Jam Well to $5 \%$ for 'Old' Indigo

\footnotetext{
${ }^{13}$ June 2007 Field Book, interviews (note 8); Berleant-Schiller, Subsistence and social organization in Barbuda (note 5).
} 


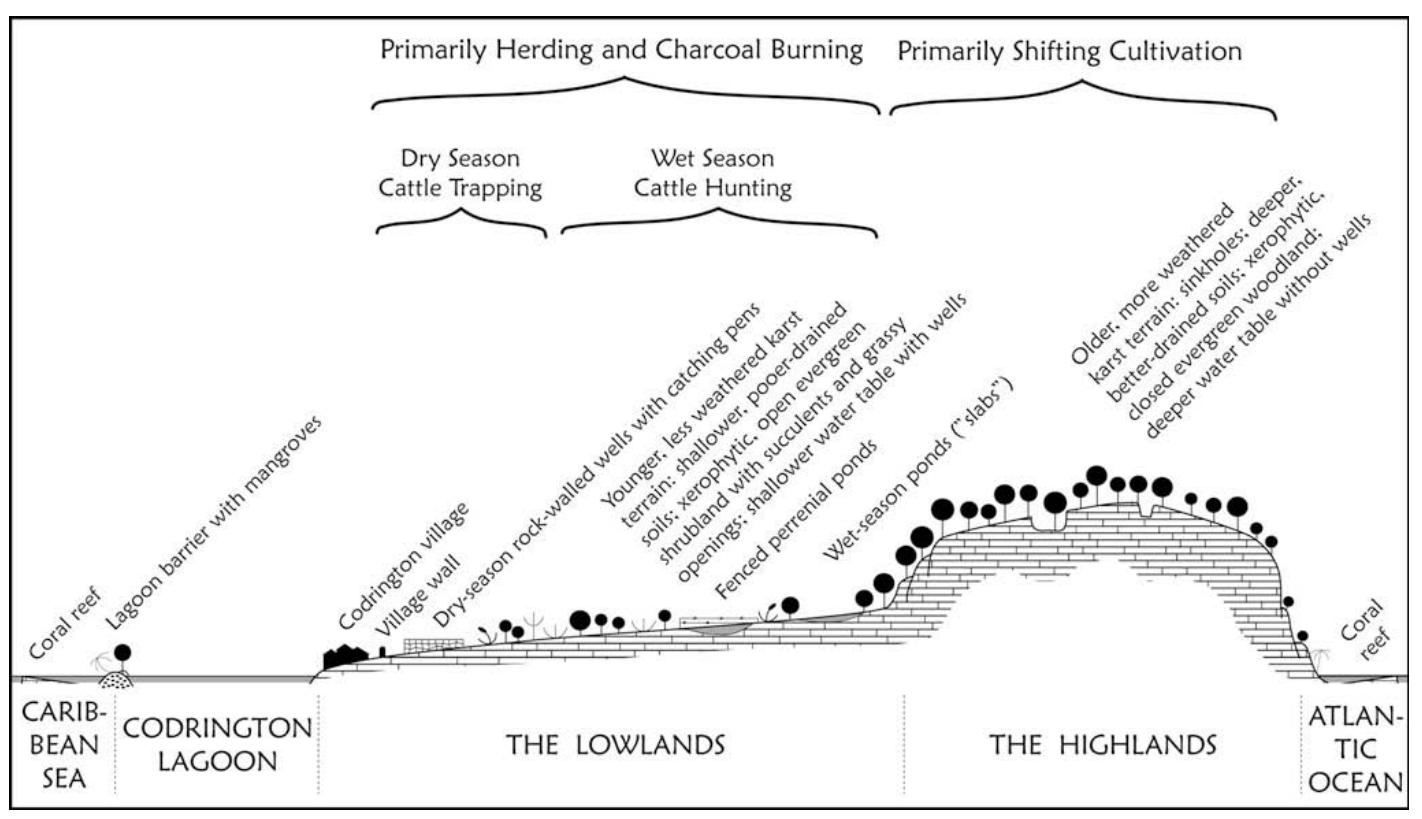

Fig. 5. Model of Barbudan herding system in 1900s.

Well. The main enclosures average $1211 \mathrm{~m}^{2}$ and the catching pens $107 \mathrm{~m}^{2}$. That variation in the dimensions of the enclosures contrasts with the relative consistency in those of the wells and troughs, and the variation does not seem related to distance from Codrington. ${ }^{14}$

A general model of herding ecology for the mid 1900s becomes apparent from the oral history of the cattle runners, Berleant-Schiller's observations in the 1970s, the forms of the walled wells, and their locations in relation to Barbuda's environmental variation (Fig. 5). The wells tap the relatively high water table of the Lowlands, which centuries of browsing and charcoal burning have cloaked in a xerophytic, open evergreen shrubland that includes succulents, thorny invasives such as acacia, and grassy openings. In contrast, wells do not tap the much deeper water table of

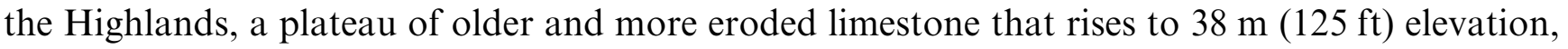
forms the cliffs of the Atlantic coast, and retains at least some of the xerophytic, closed evergreen woodland that during the 1900s supported shifting cultivation. In the wet season, finely textured soils and exposed bedrock retain surface water in solution potholes and more extensive shallow depressions throughout the Lowlands, but the deeper soils of the Highlands drain more freely and make surface water scarce. In the dry season, only two notable areas of open freshwater persist, Bull Hole and Horse Pond in the Lowlands, with several saline ponds near the coast. During

\footnotetext{
${ }^{14}$ United States Air Force, aerial photographs of 4 February 1958; Watters, Observations on the historic sites (note 5), 132; NAA, Berleant-Schiller Papers, box 3, folder labeled 'Photographs 1971,' three photographs of 'Old' Indigo Well by Jonathan Spick; D.R. Harris photographs of Beazer Well and Spring Well dating to the early 1960s, copies in possession of A. Sluyter; June 2007 Field Book, maps, sketches, and interviews (note 11); for an explanation of indigo processing, typically accomplished with three vertically arranged troughs called the steeper, beater, and sludge vats, see K.H. Beeson, Indigo production in the eighteenth century, Hispanic American Historical Review 44 (1964) 214-218.
} 
the dry season, then, as water sources progressively dried up, feral cattle would come to the walled wells near Codrington to drink, and cattle runners could relatively easily catch, brand, earmark, and cull them. Fencing around perennial ponds forced more cattle to the wells. At any time of year, but necessarily during the wet season, crews hunted down the feral cattle on the open range. ${ }^{15}$

\section{Historic cattle herding}

Various sources help to project the model of the recent system back into colonial times, including published accounts by travelers who visited Barbuda between 1790 and 1850. No matter the season of the visit, those travelers invariably noted the thorny shrubland, the modest riding horses, and the feral cattle. They variously applied the terms huntsmen and hunters to the herders, mentioned rock-walled enclosures $2 \mathrm{~m}$ in height, the use of herding dogs, of lassos thrown over horns or around rear legs, of leather hats and leggings for protection from the thorns, and of stocktrails known as avenues or rides. Some travelers provided additional details, such as how the herders used dogs to corner a cow or bull against a wall, twist the tail to bring it to its knees, and then chain it to the horns of an ox to be led to the jetty for shipment to Antigua. One identified the herding dogs as Puerto Rico bloodhounds, seemingly a reference to the Puerto Rican mastiff that closely resembles the British bullmastiff. Another, visiting in February 1790, noted how a crew of cattle runners rode horses without saddles, carried spears, and used a pack of dogs. Trelawney Wentworth, based on his visit in the $1820 \mathrm{~s}$, provided the most comprehensive description by covering both major aspects of the herding system. He described the walled wells near the village as 'rudely constructed pens around a pond, to serve as traps for the wild cattle' and noted how Codrington was 'surrounded by stone walls and wattles to prevent depredations from the wild cattle.' He also described a hunt with a crew of about half a dozen cattle runners that castrated and released young bulls as well as rounded up mature oxen for shipment to Antigua. ${ }^{16}$

The two negro huntsmen...had each six or seven horses allowed them, with two or three assistants who travelled on foot.... As soon as they find a herd, they select a young bull, which is separated, with considerable tact from his companions, and he immediately seeks safety in flight. The chase then commences...heads down, heals up; and as soon as the huntsman approaches near enough to the chase, he attempts to throw a long rope

\footnotetext{
${ }^{15}$ Harris, Plants, Animals, and Man (note 5), 25-59; J. Francis, Carlos Rivera, and J. Figureroa, Toward a Woody Plant List for Antigua and Barbuda: Past and Present, New Orleans, Louisiana, 1994; the term slabs locally designates shallow, seasonal freshwater ponds; the term flashes designates saline ponds near the coast.

${ }^{16}$ H.N. Coleridge, Six Months in the West Indies, in 1825, London, 1841, 256; C.W. Day, Five Years' Residence in the West Indies (2 vols.), London, 1852, Vol. 2, 284-296; Captain Greville quoted in T. Southey, Chronological history of the West Indies (3 vols.), London, 1827, Vol. 3, 522-524; T. Wentworth, The West India Sketch Book (2 vols.), London, 1835, Vol. 2, 240-246; Flannigan, Mrs., Antigua and the Antiguans (2 vols.), London, 1844, Vol. 1, 71; M.W. Riddell, Voyages to the Madeira and the Leeward Caribbean Isles, Salem, Massachusetts, 1802, 32-33.
} 
over the animal's horns, with such practiced dexterity that he seldom fails in his object, or in doing so, he catches the tail of the affrighted creature with his hand, and either succeeds in throwing him on his side by a singular twist of the appendage, or runs with him till he stops in a state of exhaustion.

Archival sources also describe the colonial herding system. For example, a map of 1813 shows what appears to be 'Old' Indigo Well. The main archival source for Barbuda, however, consists of the so-called Codrington Papers. They preserve letters between the Codrington family and their representatives on Barbuda and Antigua, title deeds, account books, slave inventories, maps and plans, leases, and other documents spanning the seventeenth through twentieth centuries. ${ }^{17}$

Much of the relevant Codrington correspondence relates to repeated attempts to tame cattle though the use of paddocks and controlled breeding. As early as 1720 William Codrington directed his manager to sell off all of Barbuda's wild cattle, as he called them. Many attempts followed to introduce purebred bulls and build walled pastures called parks to produce larger and tamer cattle. The inability, however, to grow sufficient hay or sustain pasture within those paddocks through the dry season rendered such efforts futile over the long term. Any tame

\footnotetext{
17 The National Archives, Kew, United Kingdom, CO 700/ANTIGUA8, the island of Barbuda as surveyed by Captain Deckar R.N., 1813; the some 8500 items in the Codrington Papers span the fifteenth through twentieth centuries and used to reside at that family's Dodington House, near Bristol, but suffered dispersal beginning in 1948 when philatelist Robson Lowe purchased 516 letters written to the Codringtons from the Caribbean between 1751 and 1855 because of their long series of early handstruck stamps, catalogued them, and resold them to diverse collectors; some refer to that group of documents as the Codrington Correspondence, and microfilm copies (1 reel) survive at the Gloucestershire Archives, formerly the Gloucestershire Record Office, and the University of Texas at Austin, the latter used herein and cited as UT Film 24,995; in the 1960s, the Codrington family placed most of their remaining documents in the Gloucestershire Archives, retaining only a few items for display at Dodington House; the Gloucestershire Archives then catalogued the collection, but Simon Codrington withdrew it to be sold at auction by Sotheby's in 1980 to an anonymous collector for $£ 106,000$, despite a bid by the government of Antigua and Barbuda on the eve of that country's independence; the Gloucestershire Archives subsequently bought back some of the Codrington Papers with funds raised in a public appeal, and in 1984 the notorious international financier Bruce Rappaport bought those pertaining to the Codrington's affairs in Antigua and Barbuda, donated them to the National Archives of Antigua and Barbuda, and built a modern archival facility to house them; that collection of documents, sometimes referred to as the Codrington West Indian Estate Papers, ranges in date from 1668 to 1944 and consist of 3459 documents organized into ten record groups, with Title Deeds, Correspondence, Plans and Maps, Accounts, and Estate being the ones cited herein as NAAB CP followed by the record group abbreviation (respectively T, C, P, A, or E) and reference to the specific document; export licensing requirements ensured that the British Library received a complete microfilm copy (RP 2616, 37 reels); a partial microfilm copy ( 7 reels) dating to 1960 has been in the Benson Latin American Collection of the University of Texas at Austin since 1971, bequeathed by J.H. Williams and indexed as Film 24,995; see R. Lowe, The Codrington Correspondence 1743-1851, London, 1951; Gloucestershire Archives D4490, Codrington archives appeal committee papers, 1981-82; R. Chamberlain, Loot: the Heritage of Plunder, New York, 1983, 185-226; Lowenthal and Clarke, Slave-breeding in Barbuda (note 5), 511-512; Tweedy, A History of Barbuda (note 5); and Coram, Caribbean Time Bomb (note 8), 182-183.
} 
herd eventually dwindled away while the feral herd grew as numerous as 5000 during the 1700s. ${ }^{18}$

Herding dogs provide another major theme. Letters, particularly in the late 1700s, refer to the need during the rainy season for more so-called bull dogs, at that time a generic term for herding and fighting dogs rather than the name of any specific breed. The account books confirm that the managers of Barbuda indeed purchased many such dogs. At the same time, William Codrington complained that using dogs only made the cattle even wilder. And one of his representatives on Antigua noted that using dogs resulted in cattle reaching market 'in a most shocking condition.' But the managers of Barbuda, such as John James in 1817, realized that whenever rainfall provided the cattle with abundant sources of surface water, herding dogs became absolutely necessary: 'We have a great many cattle, but are greatly in want of dogs to catch them, there is so much water now in the island they will not go into the pens, and the larger ones absolutely bid us defiance.' 19

Sporadic references relate to other aspects of the herding system. For example, a letter of 1740 notes how cattle used to become stuck and die in mud holes on the stocktrails until the completion of stone pavement in low spots. Letters as early as 1762 and as late as 1828 refer to manure

\footnotetext{
${ }^{18}$ NAAB CP C3, letter of February 1720 by William Codrington; C5, letter of 27 December 1740 from Benjamin King to Lady Codrington; C14/1, letters of 16 August 1783 from William Codrington to Dennis Reynolds and of 29 September 1785 from William Codrington to Joseph Lyons Walrond; C17, letters of 1 April 1792 from Dennis Reynolds to William Codrington and of 14 May 1792 from Dennis Reynolds to Christopher Bethell Codrington; C20/1-4, letters of 2 March, 17 June, 19 June, and 10 December 1790 and of February 1791 from Christopher Bethell Codrington to William Codrington; C27/2, letter of 5 November 1810 from Christopher Bethell Codrington to Samuel Martin; C29, letter of 30 August 1829 from R. Jarritt to Christopher Bethell Codrington; C31, letter of 16 March 1837 from John Winter to William Codrington; C52, letters of 24 August, 22 September, and 12 December 1860 from a Mr. Holburn to William Codrington; T9, account of the stock supposed to be on the island as of 14 July 1792 by Dennis Reynolds; UT Film 24,995, letters of 29 December 1783, 1 April 1786, and 1 March 1787 from Dennis Reynolds to William Codrington; letter of 25 September 1804 from John James to Christopher Bethell Codrington; to help make sense of the names of the letter writers and addressees, they mainly comprise the attorneys and managers of the Codrington family and its members: a Christopher Codrington (circa 1600-56) established plantations on Barbados about 1628; his son of the same name (1640-98) did so on Antigua in 1674, obtained the Barbuda lease in 1685, and became Governor General of the Leewards in 1689; his son of the same name (1668-1710) inherited the Antigua and Barbados plantations and took over the Barbuda lease in 1698 as well as succeeding his father as Governor General of the Leewards; on his death in 1710, the Society for the Propagation of the Gospel in Foreign Parts inherited the Barbados plantations while a cousin inherited the Antigua plantations and took over the Barbuda lease; that cousin, William Codrington, became the first Baronet of Dodington in 1721; upon his death in 1738, his son of the same name inherited the title and together with a younger brother, Christopher Bethell, who used his mother's maiden name, managed the Antigua plantations and Barbuda; both died in the 1790s and were succeeded by a series of Christophers and Williams, Codringtons and Bethells, and various combinations thereof; see V.T. Harlow, Christopher Codrington 1668-1710, Oxford, 1928; Lowe, The Codrington Correspondence (note 17), 1-3.

19 NAAB CP A5, 1779-82 account books for the island of Barbuda, entries for 29 April, 6 May, 13 May, and 3 June 1779; C10, letter of 18 July 1781 from Richard Clarke to William Codrington; C11, letter of 12 June 1779 from John Lindsay to William Codrington; C14/1, letters of 16 August 1783 and 22 August 1784 from William Codrington to Dennis Reynolds; C17, letters of 28 December 1781 from Dennis Reynolds to Richard Oliver and of 14 May 1792 from Dennis Reynolds to Christopher Bethell Codrington; C24, letters of 14 and 19 January 1817 from John James to Christopher Bethell Codrington; C29, letter of 16 December 1828 from Christopher Bethell Codrington to R. Jarritt; UT Film 24,995, letters of 20 August 1783 and 1 April 1786 from Dennis Reynolds to William Codrington.
} 
exports to Antigua, for use as fertilizer on the Codrington plantations. An account entry of 1781 records the purchase of four hog-skin saddles and girths 'for the use of the white people and negro hunters.' A letter of 1792 complains that Barbudan beef had a peculiar flavor because of the leaves that the cattle browsed. And a letter of 1837 reports that even after a drought of two years, the stockwells furnished 'an abundant supply of fresh water.'20

A letter by Henri de Ponthieu provides the most comprehensive account. In 1780, on a commission from William Codrington, de Ponthieu visited Barbuda to assess the potential for commercial cropping. In the process, he described the dual system of hunting cattle on the open range, mainly during the wet season, and catching them at the walled wells during the dry season. He notes such elements as the ponds that form throughout the Lowlands during the rainy season and the grassy stocktrails cleared through the shrubland. In particular, he clearly described the role of the walled wells in the system. ${ }^{21}$

The advantages from digging wells, making troughs and strong enclosures in different parts with only one opening are very great. As wild cattle are necessitated to resort in dry weather to such places where they are easily taken. This often furnishes a good opportunity of culling the males and getting the females covered.

The Codrington Papers also include a map that provides some indication of the number and distribution of walled wells during the 1700s. That map shows ten enclosures symbolized as a square with a smaller square abutting one corner, similar to the plan for Olin Well, and labeled 'watering pens where we catch cattle and horses.' The exact date of that map remains unclear but might relate to Dennis Reynolds's long tenure as manager from the 1770s to 1793. He reportedly increased the number of 'watering places' and hosted de Ponthieu, who complained that the map he was given proved so inaccurate as to be useless. And indeed the map does so distort the shape of the island and the distances and directions among recognizable landmarks that it cannot precisely locate the walled wells of the time. Seven of the ten might well correspond to the seven of the 1900s. One that clearly does not appears near the Atlantic coast, probably at a spring emerging near the base of the cliffs. The other two enclosures might relate to the now unenclosed Bumpy and Highland Wells or to other wells, now long abandoned and largely forgotten, such as the historic site known as the stone circle two kilometers south of Codrington. Certainly by 1837, three years after emancipation, one report noted the poor condition of the walled wells - with walls 'tumbling down, and out of the whole number...only one trough that will hold any quantity of water for the cattle'suggesting abandonment, rebuilding, and perhaps relocation of wells through time. While the wells of the 1900s might thus not correspond directly to those of the 1700s, clearly the general

\footnotetext{
${ }^{20}$ UT Film 24,995, letter of 5 April 1837 from J. Liggens to Christopher Codrington; NAAB CP A5, 1779-82 account books for the island of Barbuda, entry for 1 February 1781; C5, letter of 27 December 1740 from Benjamin King to Lady Codrington; C17, letter of 14 May 1792 from Dennis Reynolds to Christopher Bethell Codrington.

${ }^{21}$ NAAB CP C13, letter of 17 June 1783 from Henri de Ponthieu to William Codrington; also see UT Film 24,995, letters of 11 June, 24 August, and 27 and 28 September 1779, and of 29 July 1780 from Henri de Ponthieu to William Codrington.
} 
form of the enclosures and their location in the Lowlands rather than the Highlands has remained relatively stable over three centuries. ${ }^{22}$

Beyond projecting the operation of the herding system back at least into the $1700 \mathrm{~s}$, the Codrington Papers make clear that blacks operated it, just as they have continued to up to the present. The first few settlers of Barbuda were white, but over the 1680s blacks became the majority because Christopher Codrington brought many slaves from his Barbados plantations. By 1715, 93 of the 118 inhabitants were blacks, and the number and proportion of whites decreased even further, sometimes to a single manager, as population grew to 190 in 1756 and 314 in 1804. With population growth over the second half of the eighteenth century, Barbuda became a supplier of slaves to the Codringtons' Antiguan plantations. On the eve of emancipation, in 1832, the population had nonetheless grown to 492 , almost exclusively black. ${ }^{23}$

The number of cattle runners listed in the slave inventories never totaled more than five. In 1766, five such so-called stock hunters appear in the inventory of the first gang, meaning the middle aged and young men: Ned, Robin, Philbear, Bennar, and Tom Beazer. The 1783 inventory enumerates only two: John Bailey, a 'mustee' of 32 years; and, again, Tom Beazar, a 'mullatoo' of about 60 . As in the 1900s, the cattle runners of the 1700s enjoyed social status and did not have to look after the herding dogs or draw water for the cattle. The same 1783 inventory lists an 'old nanny' of 60 years in the grass gang, meaning the children and elderly, as 'feeding the hunting dogs' and ' 2 old women' as doing the washing for the cattle runners. The inventory also lists four males in their sixties as 'drawing water for the wild stock at your different catching pens': Scripio, Cock, Fortune, and Quashy. Reynolds argued that using the grass gang to draw water with buckets saved keeping 'a strong negro man at the wheel' of the 'water engine' introduced during the mid $1780 \mathrm{~s}^{24}$

The use of such stockwells strongly suggests African influence. Both the highland British and Spanish Andalusian cattle herders of the time could rely on surface water throughout the year and did not generally use stockwells. In contrast, the cattle herders of the sub-Saharan steppes of Africa absolutely relied on wells during the dry season, albeit not a system of rock-walled wells for trapping feral stock. Such African herders would have been among the many blacks enslaved and shipped to the British West Indies beginning in the 1600s. Those slaves, not the Codrington's white managers, certainly built the rock-walled wells of Barbuda. Speculatively, and in accord with much of the colonizer's model of a world in which blacks provide 'brawn' and whites 'brains,' a single slave master who was probably entirely unfamiliar with stockwells might have planned their construction. Or, just as speculatively but much more reasonably, given the greater

\footnotetext{
22 NAAB CP C13, letter of 17 June 1783 from Henri de Ponthieu to William Codrington; P17, map of Barbuda; UT Film 24,995, letter of 16 June 1773 from Timothy Clearkly to William Codrington; letters of 1 April 1786 from Dennis Reynolds to William Codrington; letter of 5 April 1837 from J. Liggens to Christopher Codrington; Watters, Observations on the historic sites (note 5), 130.

${ }^{23}$ Lowenthal and Clarke, Slave-breeding in Barbuda (note 5); Tweedy, A History of Barbuda (note 5), 208; J.H. Bennett, Bondsmen and Bishops: Slavery and Apprenticeship on the Codrington Plantations of Barbados, 1710-1838, Berkeley, 1958, 30, 45.

${ }^{24}$ UT Film 24,995, letter of 1 April 1786 from Dennis Reynolds to William Codrington; NAAB CP A4, list of 18 June 1766 of slaves on Barbuda; A59, account of 1 June 1783 for Barbuda; E16, inventory and appraisement of 10 October 1746.
} 
familiarity of African than British herders with wells, Barbudan blacks might also have conceived the wells and associated herding system that the white overseer and the Codringtons then profited from. ${ }^{25}$

The evidence thus demonstrates with some certainly that open-range herding on Barbuda dates back to the 1600 s and that the infrastructure of walled stockwells dates back to the 1700s. So many continuities occur between the better-known recent and poorer-known historic systems that the former legitimately serves as an analog for the latter. The major difference between the two involves slave versus free labor and associated issues such as monopoly leasehold of land and ownership of livestock in the historic system versus communal land tenure and multiple cattle owners in the recent one. The historic system would therefore not have employed branding or earmarking, since all cattle belonged to the Codringtons. The historic system also employed relatively more castration, almost exclusively for ox production rather than to manage breeding, than the recent system due to mechanization and eventual collapse of the Antiguan sugar industry after emancipation. Consideration of whether people incorporated elements of Barbudan colonial herding into the South Carolinian open-range system, perhaps together with elements of the Jamaican system, requires comparison of the three.

\section{Jamaican and South Carolinian open ranges}

The only other know open-range cattle herding system in the British West Indies began with Spaniards who brought Iberian Longhorns to Jamaica in 1509. On its seasonally flooded savannas the Spaniards readily implemented a herding system similar to that of Andalusia's coastal marshes. The herds ranged largely untended across the savannas, moving upslope in the wet season and down in the dry, and the herders wielded lances from horseback to round up the feral cattle for branding and culling. But unlike Andalusia, Jamaica's low colonial population and rapid increase in herd size resulted in the herders becoming more like hunters. They lacked a market for beef, faced a labor shortage, and therefore had neither incentive nor ability to carefully cull animals for slaughter and drive them into towns for butchering. Instead the herders learned to chase down the feral herds with dogs, added a sickle blade to the end of the Andalusian lance, and thrust it from horseback to hamstring the cattle. Hides and tallow provided the economic incentive, with most of the meat left on the ground for the dogs. Also unlike Andalusia, pigs became an integral part of the system, occupying the woodlands that bordered the savannas. ${ }^{26}$

After the British occupied Jamaica in 1655, they retained some elements of that system but implemented a fundamental modification. They retained the open range and use of dogs, familiar elements of herding for British highlanders. They retained the ancillary herding of pigs in tropical woodlands. They inherited the un-castrated longhorns, feral and unmanageable with the

\footnotetext{
${ }^{25}$ P.D. Curtin, The Atlantic Slave Trade: a Census, Madison, Wisconsin, 1969, 121-131; A.B. Smith, Pastoralism in Africa: Origins and Development Ecology, London, 1992; N. Schareika, Know to Move, Move to Know: Ecological Knowledge and Herd Movement Strategies Among the Wodaabe of Southeastern Niger, Rome, 2003.

${ }^{26}$ Jordan, North American Cattle-Ranching Frontiers (note 3), 65-78; V.A. Shepherd, Livestock and sugar: aspects of Jamaica's agricultural development from the late seventeenth to the early nineteenth century, The Historical Journal 34 (1991) 627-643.
} 
pedestrian herding practices of Britain. And thus they necessarily learned the Andalusian practice of controlling cattle from horseback. But despite those retentions, albeit with minor modifications such as replacing the Andalusian lance with the British bullwhip, the new owners of the Jamaican herds immediately began to quell the longhorns through castration and nightly penning in picketfenced enclosures, neither practice used in Andalusia but common in highland Britain. The manured ground of the cattle pens served to grow crops and by the 1670s, the Jamaican system had stabilized into a unique hybrid of British and Andalusian elements that retained the integration of pig herding in bordering woodlands and management of longhorns from horseback, albeit tame ones manageable with basic riding skills rather than the elaborate equestrianism characteristic of Andalusia. An associated mixed jargon also emerged: the Spanish corral became crawl and associated with pigs, as in hog crawl; cow pen replaced estancia to designate cattle ranch; the herders became pen keepers or cow men; and penning over referred to periodic relocation of the pens to use the manured ground for garden plots. Blacks certainly numbered among the workers but Jordan concluded they had little active involvement in the creation of the Jamaican system. $^{27}$

In the late seventeenth century, open-range cattle herding became established on South Carolina's coastal plain as about a hundred settlers from Barbados, predominantly, as well as other islands in the British Lesser Antilles and Jamaica settled near Charleston in 1670. The cattle were British breeds from the antecedent colonies of the Atlantic Seaboard, such as Virginia. The herders termed their ranches cow pens and also raised herds of pigs on so-called crawls in the woodlands that fragmented the coastal grasslands. Feral cattle ranged nearly untended. A spring roundup served for branding and castration, with the calves retained over the summer in pens of pickets woven together with vines. That practice at once protected the calves from predators and used them as bait to trap their mothers for daily milking. A fall roundup then culled the marketable steers after a summer of fattening on the range, the herders driving them to Charleston for slaughter. The calves, released from the pens, rejoined the herd to forage untended on the winter range before the next spring roundup renewed the cycle. The herders became known a cow pen keepers, rangers, cattle hunters, and crackers. They used the manure that accumulated in the pens as fertilizer for gardens of maize and vegetables. And they herded from horseback to manage the feral cattle, wielding the British bullwhip. Whether they also used dogs remains uncertain, but they did use bulldogging. Again, the herders included blacks and some have argued that practices and ideas introduced directly from West Africa must have inspired some aspects of the system. As rice plantations came to dominate South Carolina's coastal plain and the colonizers defeated the Yamassee in 1715, the open-range herders moved southwestward, reached the Louisiana-Texas borderlands by the late eighteenth century, and hybridized there with the version of the Andalusian system that had moved much more slowly northward along the Mexican coastal plain. ${ }^{28}$

Both the Barbudan and the Jamaican systems differed substantially from that of South Carolina but also shared some traits. All three relied on open range and used pens, or enclosures of

\footnotetext{
${ }^{27}$ Jordan, North American Cattle-Ranching Frontiers (note 3), 78-84.

28 G.S. Dunbar, Colonial Carolina cowpens, Agricultural History 35 (1961) 125-31; Jordan, North American CattleRanching Frontiers (note 3), 109-120, 311-312; Wood, 'It was a negro taught them' (note 4); Wood, Black Majority (note 4).
} 
some type. On Jamaica, though, tame cattle occupied the pens on a daily basis. In Barbuda and South Carolina, in contrast, the pens acted as traps for feral cattle left largely untended throughout the year. The bait differed, calves in South Carolina and water on Barbuda. The purpose differed, milking in South Carolina and culling or castrating for ox production on Barbuda. Pen construction differed, wooden pickets in South Carolina, stone walls in Barbuda. But in both systems the mature, feral stock spent little time in the pens and much time out of contact with the herders, quite unlike Jamaica.

Other commonalities remain only partially known, but none were as fundamental to the systems as the use of enclosures to trap feral cattle. The term cattle hunter was common to Barbuda and South Carolina. South Carolina and Jamaica shared the term cow pen, but it actually appeared as early as 1634 in Virginia, although to designate the enclosure itself rather than the entire ranch. South Carolina also shared the bullwhip with Jamaica and bulldogging with Barbuda. $^{29}$

\section{From the Caribbean to South Carolina}

This research provides the first good evidence for a more complex relationship between South Carolinian cattle herding and the Caribbean than a direct transfer from Jamaica alone. By providing a comprehensive reconstruction of the Barbudan system's material culture and herding ecology, it demonstrates that open-range cattle herding existed in the British Lesser Antilles during the colonial period. It demonstrates that blacks operated that system, perhaps even conceived it by drawing on African antecedents such as the key role of wells during the dry season. And it thereby suggests several additional research projects that would further amplify understanding of the role of blacks in establishing open-range cattle herding in the Caribbean and North America. That process remains so little researched and poorly understood that a long list of projects seems possible, but the Barbudan case most immediately suggests three.

One such additional project concerns whether or not the rock-walled stockwells occurred on Barbuda as early as the 1600 s, and thus early enough to affect the process that established cattle herding in South Carolina in the 1670s. The research to date leaves open the possibility that South Carolinian herding practices influenced the Barbudan system in the 1700 s rather than vice versa in the $1600 \mathrm{~s}$.

Another such additional project would address whether similar herding systems occurred on any of the other British Leewards early enough to influence both South Carolina and Barbuda, the latter perhaps no more than a surviving relict of a once more common system. The early land use of Antigua remains quite obscure and might have included a herding system similar to Barbuda's between settlement in 1632 and 1700, by when it had become a populous island of about 10,000 thoroughly dominated by sugar plantations. César de Rochefort's 1658 Histoire naturelle et morale certainly mentions herders and herds on Antigua but provides no detail.

\footnotetext{
${ }^{29}$ Dunbar, Colonial Carolina cowpens (note 28), 125, 130; Jordan, North American Cattle-Ranching Frontiers (note 3), 49, 119.
} 
Reports from 1656 and 1676 apparently note Antigua's many feral cattle and exports to Barbados. But the question of whether or not the early Antiguans used an open-range herding system similar to the Barbudan one remains the basis for an additional research project. ${ }^{30}$

The pattern of commerce and migration between the early South Carolina colony and the British Leewards, including Barbuda, also remains poorly known. The comparison of herding ecology and material culture no more than suggests a Leewards-South Carolina connection - in the same way that the existing literature no more than suggests a Jamaica-South Carolina connection. In contrast, genealogical research has revealed the name of the Spaniard who first introduced cattle herding into Mexico. ${ }^{31}$ Analysis of passenger lists to date only establishes that the majority of the white settlers of South Carolina between 1670 and 1700 with a recorded port of departure came from Barbados, that others came from Jamaica and the Leewards, and that some brought black slaves with them. Yet the question of whether or not any of those whites or blacks spent time on Barbuda and Antigua or were familiar with open-range cattle herding there, in Africa, or in highland Britain provides the basis for another additional research project. ${ }^{32}$

\section{Acknowledgements}

Sincere thanks go to many Barbudans for patience with questions and other intrusions. Amy E. Potter, Carina Giusti, Sophia A. Sluyter, and Nicole C. Sluyter assisted with field work. The Cartographic Section of the Department of Geography and Anthropology of the Louisiana State University contributed Figs 2 and 3. The staffs of the National Archives of Antigua and Barbuda, the Museum of Antigua and Barbuda, the National Anthropological Archives (United States of America), and the National Archives (United Kingdom) located and reproduced archival materials. The American Geographical Society, Foreign Military Studies Office of the US Army, and the Association of American Geographers funded the research. David R. Harris of University College London provided copies of his field photographs from the early 1960s and commented on a draft. Riva Berleant-Schiller of the University of Connecticut, Glen Richards of the University of the West Indies, Jay D. Edwards of the Louisiana State University, and the three anonymous reviewers also provided much insightful feedback.

\footnotetext{
${ }^{30}$ C. de Rochefort, Histoire naturelle et morale des îles Antilles de l'Amérique, Rotterdam, 1658, 27; Harris, Plants, Animals, and Man (note 5), 84-89, 98 cites a manuscript in the Egerton collection at the British Museum (Eg. 2395, f. 536) and another at the National Archives (CO 1/12, 68, America and West Indies colonial papers, 1653-56).

31 Sluyter, The ecological origins and consequences of cattle ranching in sixteenth-century New Spain (note 3).

32 Jordan, North American Cattle-Ranching Frontiers (note 3), 79, 109-120; A.L. Baldwin, First Settlers of South Carolina, 1670-1700, Easley, South Carolina, 1985, especially the entries for Christopher Berrow, James Proctor, Elinor Wilkens, and Henry Woodward.
} 